\title{
MODEL PENDIDIKAN KARAKTER PADA MADRASAH IBTIDAIYAH
}

\author{
Miskiah \\ Balai Diklat Keagamaan Palembang \\ Jl. Demang Lebar Daun No.4436, Ilir Bar. I, Palembang, Sumatera Selatan 30151, Indonesia \\ Email: miskiahpahrul@yahoo.co.id
}

\begin{abstract}
Abstrak
Artikel ini bertujuan untuk mengetahui: (1)konsep pendidikan karakter di Madrasah Ibtidaiyah, dan (2) model pengembangan pendidikan karakter di Madrasah Ibtidaiyah. Penelitian ini menggunakan metode kualitatif deskriptif. Pengumpulan data dilakukan dengan teknik wawancara, observasi, dan dokumentasi terhadap kegiatan pembelajaran di Madrasah Ibtidaiyah. Penelitian ini berhasil menemukan bahwa: (1) konsep pendidikan karakter di Madrasah Ibtidaiyah merupakan bentuk pendidikan yang memuat materi-materi pendidikan karakter yang diperuntukkan bagi pembelajaran anak sejak dini dalam rangka mengenalkan dan menanamkan karakter-karakter baik pada diri anak. (2) model pengembangan pendidikan karakter di Madrasah Ibtidaiyah dilakukan dengan menggunakan empat model pendekatan penyampaian, yaitu model sebagai mata pelajaran tersendiri (monolitik), model terintegrasi dalam semua bidang studi, model di luar pengajaran dan model gabungan. Dari keempat pendekatan tersebut yang cocok diterapkan di Madrasah Ibtidaiyah hanya dua, yakni: model terintegrasi pada semua bidang studi dan model gabungan.
\end{abstract}

Kata kunci: pendidikan karakter, madrasah ibtidaiyah

\section{THE MODEL OF CHARACTERISTIC EDUCATION IN MADRASAH IBTIDAIYAH}

\begin{abstract}
The purpose of this article is: (1) to describe the concept of character education in Madrasah Ibtidaiyah, (2) to describe the development of character education model in Madrasah Ibtidaiyah. This study was a descriptive qualitative method. The data were collected through interviews, observation and documentation. The results of this study are: (1) the concept of character education in Madrasah Ibtidaiyah is a form of education that contains the materials of character education which given to the teaching and learning of the children.(2) There are several models of implementation of character education in Madrasah Ibtidaiyah, a) Model as an individual subject (monolithic), b) Integrated model in all field of study, c) Model outside of teaching, d) Combined model. There only two approaches that can be applied in Madrasah Ibtidaiyah: integrated model in all field of study and combined model.
\end{abstract}

Keywords: character eduction, madrasah ibtidaiyah 


\section{PENDAHULUAN}

Konsep dasar pendidikan karakter sekaligus implementasinya pada tingkat SD/MI dengan berbagai karakteristik perkembangan psikis tentu berbeda dengan perkembangan psikis peserta didik pada jenjang berikutnya.

Pendidikan karakter menjadi isu strategis untuk dibahas melihat krisis moral yang yang terjadi belakangan ini. Di mana, hampir semua kasus yang terjadi berkaitan dengan dekadensi moral ditengarai akibat kegagalan pendidikan karakter yang diberikan oleh lembaga-lembaga pendidikan. Contoh kasus nyata ialah 158 kepala daerah tersangkut korupsi sepanjang 2004-2011, 42 anggota DPR terseret korupsi pada kurun waktu 2008-2011, 30 anggota DPR periode 1999-2004 terlibat kasus suap pemilihan DGS BI. Kasus korupsi terjadi diberbagai lembaga seperti KPU,KY, KPPU, Ditjen Pajak, BI, dan BKPM (Wibowo, 2010).

Hasil penelitian di Harvard University, Amerika Serikat, yang menyatakan bahwa ternyata kesuksesan seseorang tidak ditentukan semata-mata oleh pengetahuan dan kemampuan teknis (hard skill), tetapi oleh kemampuan mengolah diri dan orang lain (soft skill). Penelitian ini mengungkapkan bahwa kesuksesan hanya ditentukan sekitar $20 \%$ oleh hard skill, dan sisanya $(80 \%)$ oleh soft skill. Bahkan, orang-orang tersukses didunia bisa berhasil dikarenakan lebih banyak didukung oleh kemampuan soft skill dari pada hard skill. Hal ini mengisyaratkan bahwa mutu pendidikan karakter peserta didik sangat penting untuk ditingkatkan (Asmani, 2012, p. 47).

Proses pendidikan selama ini ternyata belum berhasil membangun manusia Indonesia yang berkarakter. Banyak lulusan sekolah dan sarjana yang pandai menjawab soal dan berotak cerdas, tapi perilakunya tidak terpuji. Inilah mengapa pendidikan karakter sangat penting dan dibutuhkan sesegera mungkin (Battel \& Shannon, 1978, p. 33).

Untuk itulah, pemerintah menyadari perlunya pembentukan karakter mulai usia dini. Namun, pendidikan karakter yang paling tepat diterapkan secara menyeluruh ada pada usia jenjang pendidikan dasar, dimana usia jenjang pendidikan dasar merupakan usia emas dalam pembentukan karakter, watak, dan kepribadian seseorang. Fadiman (1984) menyatakan bahwa sekolah/madrasah kini masih merupakan peta utama atau sebagai satu-satunya peta untuk pulau harta karun yang merasuk pada pikiran peserta didik.

Jenjang pendidikan dasar juga merupakan fondasi awal untuk melangkah ke pendidikan yang lebih lanjut. Bila penanaman karakter gagal dilakukan pada tahap usia pendidikan dasar, maka bisa dipastikan, karakter yang tertanam pada peserta didik kurang optimal. Pengembangan pendidikan berkarakter bagi peserta didik harus diterapkan sungguhsungguh karena kepribadian dan karakter yang kuat akan berpengaruh di masa depan. Anak usia Madrasah Ibtidaiyah merupakan masa kritis dalam pembentukan karakter. Menurut Freud, kegagalan dalam memberikan penanaman dan pembinaan kepribadian berkarakter pada anak usia Madrasah Ibtidaiyah akan membentuk pribadi yang bermasalah pada saat dewasa.

Berdasarkan persoalan-persoalan tersebut, maka dalam artikel ini akan menguraikan tentang konsep pendidikan karakter di Madrasah Ibtidaiyah dan karakteristik model pendidikan karakter di Madrasah Ibtidaiyah. Semuanya dimaksudkan sebagai usulan alternatif pendidikan karakter di Madrasah Ibtidaiyah di Indonesia.

\section{METODE PENELITIAN}

Penelitian ini menggunakan metode kualitatif deskriptif, yaitu sebuah penelitian yang menggambarkan kondisi secara alamiah (Sugiyono, 2011, pp. 8-9). Metode ini dimaksudkan untuk menggambarkan secara umum kurikulum dan kegiatan pembelajaran di Madrasah Ibtidaiyah. Untuk pengumpulan data dalam penelitian ini dilakukan dengan menggunakan tiga cara, yaitu observasi, wawancara, dan dokumentasi. Ketiga teknik pengumpulan data tersebut digunakan untuk mengumpulkan berbagai informasi yang terkait dengan kurikulum pendidikan multikultural dan kegiatan pembelajaran di Madrasah Ibtidaiyah. Adapun yang menjadi subjek penelitian ini, meliputi: kepala sekolah, guru, dan siswa di Madrasah Ibtidaiyah di Kota Palembang.

\section{PEMBAHASAN}

\section{Pengertian Karakter}

Kesuma, Triatna, \& Permana (2011, p. 11) menyatakan bahwa karakter adalah suatu 
nilai yang diwujudkan dalam bentuk perilaku, jadi suatu karakter melekat melekat dengan nilai dari perilaku tersebut. Sedangkan Suyanto (Zubaedi, 2011, p. 11) menyatakan bahwa karakter adalah cara berpikir dan berperilaku yang menjadi ciri khas tiap individu untuk hidup dan bekerja sama, baik dalam lingkungan keluarga, masyarakat, bangsa, dan negara.

Selanjutnya, Samani \& Hariyanto (2011, p. 43) mengungkapkan bahwa karakter dimaknai sebagai nilai dasar yang membangun pribadi seseorang, terbentuk baik karena pengaruh hereditas maupun pengaruh lingkungan, yang membedakan dengan orang lain, serta diwujudkan dalam sikap dan perilaku kehidupan sehari-hari. Senada dengan hal itu, Muslich (2011, p. 84) menyatakan bahwa karakter merupakan nilai-nilai perilaku manusia yang berhubungan dengan Tuhan Yang Maha Esa, diri sendiri, sesama manusia, lingkungan, dan kebangsaan yang terwujud dalam pikiran, sikap, perasaan, dan perbuatan berdasarkan norma agama, hukum, tata krama, budaya, dan adat istiadat.

Secara umum menurut Koesoema (2010, p. 79) mengemukakan bahwa karakter dapat didefinisikan sebagai unsur psikososial yang dikaitkan dengan pendidikan dan konteks lingkungan. Karakter jika dipandang dari sudut behavioral yang menekankan unsur kepribadian yang dimiliki individu sejak lahir. Karakter dianggap sama dengan kepribadian, karena kepribadian dianggap sebagai ciri atau karakteristik atau sifat khas dari diri seseorang yang bersumber dari lingkungan. Dari beberapa pendapat di atas, maka peneliti menyimpulkan bahwa karakter merupakan nilai-nilai yang terwujud dalam sikap dan perilaku yang memiliki hubungan dengan lingkungan berdasarkan dengan norma yang ada dalam masyarakat.

\section{Konsep Pendidikan Karakter}

Muslich (2011, p. 84) mengungkapkan bahwa pendidikan karakter adalah suatu sistem penanaman nilai-nilai karakter kepada warga sekolah yang meliputi komponen pengetahuan, kesadaran atau kemauan, dan tindakan untuk melaksanakan nilai-nilai tersebut, baik terhadap Tuhan Yang Maha Esa, diri sendiri, lingkungan, dan negara menjadi manusia yang kamil. Senada dengan hal itu, Samani \& Hariyanto (2011, p. 45) menyampaikan bahwa pendidikan karakter adalah proses pemberian tuntunan kepada peserta didik untuk menjadi manusia seutuhnya yang berkarakter dalam dimensi hati, pikir, raga, serta rasa dan karsa.

Deny Setiawan mengutip pendapat Kirschenbaum (2000) dan Goleman (2001) menjelaskan bahwa pendidikan karakter pada hakikatnya adalah pendidikan nilai yang melibatkan aspek pengetahuan (cognitive), perasaan (feeling), dan tindakan (action). Senada dengan hal itu, Lickona (2008) mengemukakan bahwa pendidikan nilai/moral yang menghasilkan karakter, didalamnya mengandung tiga komponen karakter yang baik, yakni : pengetahuan tentang moral (moral knowing), perasaan tentang moral (moral feeling) dan perbuatan moral (moral action). Tindakan (moral action) yang meliputi: dorongan berbuat baik, kompetensi, keinginan, kebiasaan (habit). Perasaan (moral feeling) yang meliputi: kata hati, rasa percaya diri, empati, cinta kebaikan, pengendalian diri dan kerendahan hati. Pengetahuan (moral Knowing) yang meliputi: kesadaram moral, pengetahuan nilai-moral, pandangan kedepan,penalaran moral, pengambilan keputusan dan pengetahuan peserta didik.

Tujuan Pendidikan Karakter dalam Seting Sekolah

Analisis yang dilakukan oleh Pusat Pengkajian Pedagogia (Kesuma et al., 2011, p. 6) dapat dijadikan sebagai salah satu tinjauan tentang tujuan pendidikan nasional. Tujuan pendidikan nasional tidak boleh melupakan landasan konseptual filosofi pendidikan yang membebaskan dan mampu menyiapkan generasi masa depan untuk dapat bertahan hidup (survive) dan berhasil menghadapi tantangantantangan zaman.

Pendidikan nasional seharusnya mengembangkan berbagai karakter agar menjadi manusia Indonesia yang seutuhnya, sehingga pendidikan karakter bukan pendidikan akademik semata. Sependapat dengan hal itu, Sunaryo Kartadinata (Kesuma et al., 2011, p. 8) menyatakan bahwa ukuran keberhasilan pendidikan yang berhenti pada angka ujian, seperti halnya Ujian Nasional, adalah kemunduran. Dengan demikian pembelajaran akan menjadi sebuah proses menguasai keterampilan dan mengakumulasi pengetahuan.

Senada dengan hal itu, Buchori (Muslich, 2011, p. 87) mengungkapkan bahwa pendidikan karakter seharusnya membawa 
peserta didik ke pengenalan nilai secara kognitif, penghayatan nilai secara afektif dan akhirnya ke pengenalan nilai secara nyata. Selanjutnya, Kesuma et al. (2011, p. 9) menungkapkan bahwa tujuan pendidikan karakter dalam seting sekolah antara lain adalah; (a) menguatkan dan mengembangkan nilai-nilai kehidupan yang dianggap penting dan perlu sehingga menjadi kepribadian/kepemilikan peserta didik yang khas sebagaimana nilai-nilai yang dikembangkan; (b) mengoreksi perilaku peserta didik yang tidak bersesuaian dengan nilainilai yang dikembangkan oleh sekolah; (c) membangun koneksi yang harmoni dengan keluarga dan masyarakat dalam memerankan tanggung jawab pendidikan karakter secara bersama.

Tujuan pertama pendidikan karakter adalah memfasilitasi penguatan dan pengembangan nilai-nilai tertentu sehingga terwujud dalam perilaku anak, baik ketika proses sekolah maupun setelah proses sekolah (setelah lulus dari sekolah). Selanjutnya, Muslich (2011, p. 88) mengungkapkan bahwa keberhasilan pendidikan karakter dapat diketahui melalui pencapaian indikator oleh peserta didik sebagaimana tercantum dalam Standar kompetensi Lulusan, yang antara lain meliputi sebagai berikut: (1) mengamalkan ajaran agama yang dianut sesuai dengan tahap perkembangan remaja; (2) memahami kelebihan dan kekurangan diri sendiri; (3) menunjukkan sikap percaya diri; (4) mematuhi aturan-aturan sosial yang berlaku dalam lingkungan yang lebih luas; (5) menghargai keberagaman agama, budaya, suku, ras dan golongan sosial ekonomi dalam lingkup nasional; (6) mencari dan menerapkan informasi dari lingkungan sekitar dan dari sumber-sumber lain secara logis, kritis dan kreatif; (7) menunjukkan kemampuan berpikir logis, kritis, kreatif dan inovatif; (8) menunjukkan kemampuan belajar secara mandiri sesuai dengan potensi yang dimilikinya; (9) menunjukkan kemampuan menganalisis dan memecahkan masalah dalam kehidupan sehari-hari; (10) mendeskripsikan gejala alam dan sosial; (11) memanfaatkan lingkungan secara bertanggung jawab; (12) menerapkan nilai-nilai kebersamaan dalam kehidupan bermasyarakat, berbangsa, dan bernegara demi terwujudnya persatuan dalam Negara kesatuan Republik Indonesia; (13) menghargai karya seni dan budaya nasional, (15) menghargai tugas pekerjaan dan memiliki kemampuan untuk berkarya; (15) menerapkan hidup bersih, sehat, bugar, aman, dan memanfaatkan waktu luang dangan baik; (16) berkomunikasi dan berinteraksi secara efektif dan santun; (17) memahami hak dan kewajiban diri dan orang lain dalam pergaulan di masyarakat, menghargai perbedaan pendapat; (18) menunjukkan kegemaran membaca dan menulis naskah pendek sederhana; (19) menunjukkan keterampilan menyimak, berbicara, membaca, dan menulis dalam bahasa Indonesia dan bahasa Inggris sederhana; (20) menguasai pengetahuan yang diperlukan untuk pengikuti pendidikan menengah; (21) memiliki jiwa kewirausahaan.

\section{Karakteristik Anak}

Sebagai seorang pendidik, sangatlah penting bagi seorang guru untuk mengetahui karakteristik siswanya agar pendidik dapat menerapkan metode pengajaran yang sesuai dengan keadaan siswanya. Selain karakteristik, pendidik juga perlu memperhatikan kebutuhan peserta didiknya.

Anak Madrasah Ibtidaiyah (MI) merupakan anak dengan kategori banyak mengalami perubahan yang sangat drastis baik mental maupun fisik. Usia anak SD/MI menurut Izzaty, Suardiman, Ayriza, Hiryanto, \& Kusmaryani (2008, pp. 119-121) memiliki enam jenis perkembangan:

\section{Perkembangan Fisik Siswa SD}

Pertumbuhan fisik cenderung lebih stabil atau tenang, anak menjadi lebih tinggi, lebih berat, lebih kuat serta belajar berbagai ketretampilan. Perubahan nyata terlihat pada sistem tulang, otot dan keterampilan gerak berlari, memanjat, melompat, berenang, naik sepeda, main sepatu roda adalah kegiatan fisik dan keterampilan gerak yang banyak dilakukan oleh anak. Pada prinsipnya selalu aktif bergerak penting bagi anak. Perbedaan seks dalam pertumbuhan fisik menonjol disbanding tahuntahun sebelumnya yang hampir tidak nampak.

\section{Perkembangan Kognitif Siswa SD}

Jean Piaget (Sugihartono, Fathiyah, Harahap, Setiawati, \& Nurhayati, 2007, p. 109) mengungkapkan bahwa tahap perkembangan berpikir individu ialah melalui empat stadium: (a) Sensorimotorik (0-2 tahun), bayi lahir dengan sejumlah refleks bawaan medorong mengeksplorasi dunianya, (b) Praoperasional (2-7 tahun), anak belajar menggunakan dan 
merepresentasikan objek dengan gambaran dan kata-kata, (c) Operational Kongkret (7-11), penggunaan logika yang memadai. Tahap ini telah memahami operasi logis dengan bantuan benda konkrit, (d) Operasional Formal (12-15 tahun). kemampuan untuk berpikir secara abstrak, menalar secara logis, dan menarik kesimpulan dari informasi yang tersedia.

\section{Perkembangan Bahasa}

Pada masa ini perkembangan bahasa nampak pada perubahan perbendaharaan kata dan tata bahasa. Bersamaan dengan masa sekolah, anakanak semakin banyak menggunakan kata kerja seperti memukul, melempar, menendang dan menampar. Anak kelas satu merespon pertanyaan orang dewasa dengan jawaban yang lebih sederhana dan pendek. Belajar membaca dan menulis membebeskan anak-anak dari keterbatasan untuk berkomunikasi langsung. Menulis merupakan tugas yang dirasa lebih sulit dari pada membaca bagi anak. Membaca memiliki peran penting dalam pengembangan bahasa.

\section{Perkembangan Moral}

Perkembangan moral ditandai dengan kemampuan anak untuk memahami aturan, norma dan etika yang berlaku di masyarakat. Perilaku moral banyak dipengaruhi oleh pola asuh orang tuanya serta perilaku moral dari orang-orang disekitarnya.

\section{Perkembangan Emosi}

Emosi melakukan peran yang penting dalam kehidupan anak. Akibat dari emosi ini juga dirasakan oleh fisik anak terutama bila emosi itu kuat dan berulang-ulang. Pergaulan yang semakin luas membawa anak belajar bahwa ungkapan emosi yang kurang baik tidak diterima oleh teman-temanya. Anak belajar mengendalikan ungkapan-ungkapan emosi yang kurang dapat diterima seperti: amarah, menyakiti perasaan teman, ketakutan dan sebagainya.

\section{Perkembangan Sosial}

Perkembangan emosi pada masa anakanak akhir tak bisa dipisahkan dengan perkembangan sosial, yang sering disebut dengan perkembangan tingkah laku sosial. Orang-orang di sekitarnyalah yang banyak mempengaruhi perilaku sosialnya. Dunia sosioemosional anak menjadi semakin kompleks dan berbeda dengan masa ini. Interaksi dengan keluarga, teman sebaya, sekolah dan hubungan dengan guru memiliki peran penting dalam hidup anak. Pemahaman tentang diri dan dan perubahan dalam perkembangan gender dan moral menandai perkembangan anak selama masa kanak-kanak akhir. Bermain secara berkelompok memberikan peluang dan pelajaran kepada anak untuk berinteraksi, bertenggang rasa dengan sesame teman. Permainan yang disukai cenderung bermain berkelompok. Pengaruh teman sebaya sangat besar baik yang bersifat positif seperti pengembangan konsep diri dan pembentukan harga diri, maupun negatif

\section{Nilai-nilai Karakter}

Soekamto (Muslich, 2011, p. 79), mengungkapkan bahwa nilai-nilai karakter yang perlu diajarkan pada anak, meliputi kejujuran, loyalitas dan dapat diandalkan, hormat, cinta, ketidak egoisan dan sensitifitas, baik hati dan pertemanan, keberanian, kedamaian, mandiri dan potensial, disiplin diri, kesetiaan dan kemurnian, keadilan dan kasih sayang. Selanjutnya, dalam kaitan pada Grand Design pendidikan karakter Samani \& Hariyanto (2011, p. 51) mengungkapkan bahwa nilai-nilai utama yang akan dikembangkan dalam budaya satuan pendidikan formal dan nonformal, yaitu jujur, tanggung jawab, cerdas, sehat dan bersih, peduli, kreatif, dan gotong royong.

Senada dengan pendapat di atas, Listyarti (2012, pp. 5-8) menjabarkan 18 nilainilai dalam pengembangan pendidikan budaya dan karakter bangsa yang dibuat oleh Diknas. 18 nilai-nilai tersebut adalah :

1. Religius: sikap dan perilaku yang patuh dalam melaksanakan ajaran agama yang dianutnya, toleran terhadap pelaksanaan ibadah agama lain, dan hidup rukun dengan pemeluk agama lain. Religius adalah proses mengikat kembali atau bisa dikatakan dengan tradisi, system yang tata keimanan (kepercayaan) dan peribadatan kepada Tuhan Yang Mahakuasa serta tata kaidah yang berhubungan dengan pergaulan manusia dan manusia serta lingkunganya.

2. Jujur: perilaku yang didasarkan pada upaya menjadikan dirinya sebagai orang yang selalu dapat dipercaya dalam perkataan, tindakan, dan pekerjaan. 
3. Toleransi: sikap dan tindakan yang menghargai perbedaan agama, suku, etnis, pendapat, sikap, dan tindakan orang lain yang berbeda dari dirinya.

4. Disiplin: tindakan yang menunjukkan perilaku tertib dan patuh pada berbagai ketentuan dan peraturan.

5. Kerja Keras: perilaku yang menunjukkan upaya sungguh-sungguh dalam mengatasi berbagai hambatan belajar dan tugas, serta menyelesaikan tugas dengan sebaik-baiknya.

6. Kreatif: berpikir dan melakukan sesuatu untuk menghasilkan cara atau hasil baru dari sesuatu yang telah dimiliki.

7. Mandiri: sikap dan perilaku yang tidak mudah tergantung pada orang lain dalam menyelesaikan tugas-tugas.

8. Demokratis: cara berfikir, bersikap, dan bertindak yang menilai sama hak dan kewajiban dirinya dan orang lain.

9. Rasa Ingin Tahu: sikap dan tindakan yang selalu berupaya untuk mengetahui lebih mendalam dan meluas dari sesuatu yang dipelajarinya, dilihat, dan didengar.

10. Semangat Kebangsaan: cara berpikir, bertindak, dan berwawasan yang menempatkan kepentingan bangsa dan negara di atas kepentingan diri dan kelompoknya.

11. Cinta Tanah Air: cara berpikir, bertindak, dan berbuat yang menunjukkan kesetiaan, kepedulian, dan penghargaan yang tinggi terhadap bahasa, lingkungan fisik, social, budaya, ekonomi, dan politik bangsa.

12. Menghargai Prestasi: sikap dan tindakan yang mendorong dirinya untuk menghasilkan sesuatu yang berguna bagi masyarakat, dan mengakui, serta menghormati keberhasilan orang lain.

13. Bersahabat/Komunikatif: tindakan yang memperlihatkan rasa senang berbicara, bergaul, dan bekerja sama dengan orang lain.

14. Cinta Damai: sikap, perkataan, dan tindakan yang menyebabkan oranglain merasa senang dan aman atas kehadiran dirinya. Diri sendiri, masyarakat, lingkungan (alam, social, dan budaya), negara.

15. Gemar Membaca: kebiasaan menyediakan waktu untuk membaca berbagai bacaan yang memberikan kebajikan bagi dirinya.

16. Peduli Lingkungan: sikap dan tin-dakan yang selalu berupaya mencegah kerusak- an pada lingkungan alam di sekitarnya, dan mengembangkan upaya-upaya untuk memperbaiki kerusakan alam yang sudah terjadi.

17. Peduli Sosial: sikap dan tindakan yang selalu ingin memberi bantuan pada orang lain dan masyarakat yang membutuhkan.

18. Tanggung Jawab: sikap dan perilaku seseorang untuk melaksanakan tugas dan kewajibannya, yang seharusnya dia lakukan, terhadap dirinya maupun orang lain dan lingkungan sekitarnya.

\section{Pendidikan Karakter di Madrasah Ibtidaiyah}

Madrasah sebagai lembaga pendidikan merupakan wadah yang benar-benar memenuhi elemen-elemen institusi yang tidak terjadi pada lembaga-lembaga pendidikan lain. Tugas yang diemban oleh madrasah setidaknya mencerminkan sebagai lembaga pendidikan Islam yang berbeda. Menurut An-Nahlawi, tugas lembaga madrasah sebagai lembaga pendidikan Islam adalah:

1. Merealisasikan pendidikan Islam yang didasarkan pada prinsip pikir, aqidah dan Tasyri' yang diarahkan untuk mencapai tujuan pendidikan bentuk dan realisasi itu ialah agar peserta didik beribadah, mentauhidkan Allah SWT, tunduk dan patuh atas perintahnya, serta syariatnya.

2. Memelihara fitrah peserta didik sebagai insan yang mulia agar ia tidak menyimpang dari tujuan Allah yang telah menciptakan. Oleh karena itu, dasar operasionalisasi pendidikan harus dijiwai oleh fitrah manusiawi, sehingga menghindari adanya penyimpangan.

3. Memberikan kepada peserta didik dengan seperangkat peradaban dan kebudayaan Islam, dengan cara mengintegrasikan antara ilmu alam, ilmu social, ilmu eksakta dengan landasan ilmu agama sehingga peserta didik mampu melibatkan dirinya pada perkembangan IPTEK.

4. Membersihkan pikiran dan jiwa dari pengaruh emosi karena pengaruh globalisasi, madrasah berperan sebagai benteng yang menjaga kebesihan dan keselamatan fitrah manusia.

5. Memberikan wawasan nilai dan moral, serta peradaban manusia yang membawa hasanah perkembangan berfikir peserta didik. 
6. Menciptakan suasana kesatuan dan kesamaan antar peserta didik.

7. Tugas mengkordinasi dan membenahi kegiatan pendidikan

8. Menyempurnakan tugas-tugas lembaga pendidikan keluarga, masjid dan pesantren.

Madrasah Ibtidaiyah sebagai suatu lembaga pendidikan dasar Islam yang lebih modern, yang memadukan antara pendidikan pesantren dan sekolah, yang materinya mengintegrasikan agama dan pengetahuan umum. Madrasah sebagai lembaga pendidikan Islam berfungsi menghubungkan sistem lama dan sistem baru dengan jalan mempertahankan nilai-nilai lama yang masih baik dan dapat dipertahankan dan mengambil sesuatu yang baru dalam ilmu, teknologi, dan ekonomi yang bermanfaat bagi kehidupan umat Islam, sedangkan isi kurikulum madrasah pada umumnya sama dengan pendidikan di pesantren ditambah dengan ilmu-ilmu umum (Nashir, 2013, p. 27).

Misi jenjang pendidikan dasar adalah berupaya menggali dan mengembangkan seluruh potensi dan dimensi baik personal, agama, susila dan sosial yang dimiliki peserta didik. Melalui usaha ini memungkinkan setiap peserta didik, tanpa kecuali, dapat mendorong tumbuh nilai-nilai kejujuran, keadilan, kasih sayang, toleransi, keindahan, dan tanggung jawab dalam pemahaman nilai sesuai tingkat perkembangan dan kemampuan mereka. Madrasah ibtidaiyah merupakan salah satu jenjang pengembangan potensi dasar yang dimiliki anak. Keberhasilan dalam membimbing peserta didik dalam konflik kepribadian pada usia pendidikan dasar akan sangat menentukan interaksi kehidupan bermasyarakat pada saat beranjak dewasa. Inilah yang menjadi tugas penting bagi orang tua, pendidik, dan masyarakat di sekitar lingkungan peserta didik itu tinggal. Pembentukan karakter adalah bagian integral dari orientasi pendidikan Islam. Proses penerapan pendidikan karakter pada anak usia madrasah ibtidaiyah harus melibatkan aspek perkembangan peserta didik, baik kognitif, afektif, maupun psikomotorik harus menjadi satu keutuhan yang tidak bisa dipisah satu sama lain. Bila tanpa satu dari 3 aspek perkembangan tersebut, maka penerapan pendidikan karakter akan sulit dilaksanakan. Tujuannya adalah membentuk kepribadian seseorang agar berperilaku jujur, baik, bertanggung jawab, menghormati dan menghargai orang lain, adil tidak diskriminatif, pekerja keras, dan karakter-karakter unggul lainnya.

\section{Prinsip Pendidikan Karakter di Madrasah Ibtidaiyah}

Berangkat dari pentingnya nilai pendidikan karakter bagi bangsa ini, maka perlu pedoman untuk mengimplementasikannya agar mendapatkan hasil yang maksimal. Pedoman yang dimaksud adalah prinsip-prinsip pendidikan karakter yang akan menjadi sebuah formulasi kolektif yang saling berkaitan antara satu dengan yang lainnya, sehingga menjadi satu kesatuan yang terintegrasi secara utuh. Secara sederhana, prinsip adalah suatu pernyataan fundamental atau kebenaran umum maupun individual yang dijadikan oleh seseorang atau kelompok sebagai pedoman untuk berpikir atau bertindak. Menurut Syarbni (2012, pp. 35-38), untuk dapat mengimplementasikan program pendidikan karakter yang efektif, seyogianya memenuhi beberapa prinsip berikut:

a. Komunitas Madrasah Ibtidaiyah mengembangkan dan meningkatkan nilai-nilai inti etika dan kinerja sebagai landasan karakter yang baik. Pada usia madrasah ibtidaiyah, penanaman pendidikan karakter bisa diterapkan dengan cara menanamkan keteladanan. Misalnya, pemimpin harus memberi teladan yang baik untuk bawahannya sehingga bawahan akan terajak berbuat baik sesuai dengan perilaku pimpinannya

b. Madrasah Ibtidaiyah berusaha mendefinisikan "karakter" secara komprehensif, didalamnya mencakup berpikir, merasa, dan melakukan.

c. Madrasah Ibtidaiyah menggunakan pendekatan yang komprehensif, intensif, dan proaktif dalam pengembangan karakter. Pendidikan karakter dimaksudkan untuk membentuk sosok manusia yang kuat dan tidak mudah goyah dalam menghadapi segala permasalahan yang ada. Pendidikan karakter juga menjadi wujud pewarisan kebudayaan karena dengan pendidikan karakter, peserta didik dibentuk untuk tetap berpedoman pada nilai-nilai luhur yang telah ada.

d. Madrasah Ibtidaiyah menciptakan sebuah komunitas yang memiliki kepedulian 
yang tinggi. Lingkungan sekolah harus mendukung adanya pengembangan pendidikan karakter dengan menciptakan situasi dan lingkungan belajar yang sesuai dan dapat dijadikan model pembelajaran peserta didik. Pembelajaran lebih ditekankan pada cara belajar peserta didik aktif yang lebih efektif dalam mengembangkan kemampuan dasar peserta didik.

e. Madrasah Ibtidaiyah menyediakan kesempatan yang luas bagi para peserta didik untuk melakukan berbagai tindakan moral. Pendidikan dasar harus memfasilitasi peserta didik untuk belajar lebih bebas dan mempunyai pandangan sendiri yang disertai dengan rasa tanggung jawab pribadi yang lebih kuat untuk mencapai tujuan hidup pribadinya atau tujuan bersama sebagai anggota masyarakat.

f. Madrasah Ibtidaiyah menyediakan kurikulum akademik yang bermakna Strategi pengembangan kurikulum pendidikan dasar adalah penekanan pada 4 (empat) pilar pendidikan yang ditetapkan UNESCO, yaitu belajar mengetahui (learning to know), menjadi dirinya sendiri (learning to be), belajar bekerja (learning to do) dan belajar hidup bersama (learning to live together). Pengembangan kurikulum (program belajar) dapat menghargai dan menghormati seluruh peserta didik, mengembangkan karakter mereka, dan berusaha membantu mereka untuk meraih berbagai kesuksesan.

g. Madrasah Ibtidaiyah mendorong peserta didik untuk memiliki motivasi diri yang kuat.

h. Staf Madrasah Ibtidaiyah adalah komunitas belajar etis yang senantiasa berbagi tanggung jawab.

i. Madrasah Ibtidaiyah mendorong kepemimpinan bersama yang memberikan dukungan penuh terhadap gagasan pendidikan karakter dalam jangka panjang. Pendidikan madrasah ibtidaiyah sebagai salah satu jenjang pendidikan dalam sistem pendidikan nasional yang merupakan fondasi dasar dalam menentukan bagaimana proses pendidikan berikutnya oleh karena itu pendidikan madrasah ibtidaiyah mengutamakan pembentukan watak, karakter, dan kepribadian anak.

j. Madrasah Ibtidaiyah melibatkan keluarga dan masyarakat sebagai mitra dalam upa- ya pembangunan karakter. Pendidikan dasar merupakan pendidikan lanjutan dari pendidikan keluarga, karena itu, kerja sama antara sekolah dengan keluarga merupakan hal yang sangat penting. Sekolah tidak akan berhasil mengembangkan pendidikan karakter tanpa peran aktif orang tua, begitu juga dengan komunitas masyarakat sejatinya harus sinergis dan harmonis.

k. Secara teratur, Madrasah Ibtidaiyah melakukan assessment terhadap budaya dan iklim sekolah, keberfungsian para staf sebagai pendidik karakter di sekolah, dan sejauh mana peserta didik dapat mewujudkan karakter yang baik dalam kehidupan sehari-hari.

Mendukung prinsip diatas, bahwa pendidikan karakter itu tidak dapat dikembangkan secara cepat dan segera, tetapi harus melewati proses yang panjang, cermat, dan sistematis. Berdasarkan perspektif yang berkembang dalam sejarah pemikiran manusia, pendidikan karakter harus dilakukan berdasarkan tahapan-tahapan perkembangan anak sejak usia dini sampai dewasa. Setidaknya, berdasarkan psikolog dan ahli pendidikan dasar (Marlene Lockheed \& Verspoor, Kohlberg, dalam Suryadi, 2011), terdapat empat tahapan pendidikan karakter yang perlu dilakukan, yaitu:

a. Tahapan pembiasaan, sebagai awal perkembangan karakter anak.

b. Tahap pemahaman dan penalaran terhadap nilai, sikap, perilaku, dan karakter peserta didik.

c. Tahap penerapan berbagai perilaku dan tindakan peserta didik dalam kenyataan sehari-hari.

d. Tahap pemaknaan, yaitu suatu tahap refleksi dari para peserta didik melalui penilaian terhadap seluruh sikap dan perilaku yang telah merekapahami dan lakukan dan bagaimana dampak dan kemanfaatannya dalam kehidupan, baik bagi dirinya maupun orang lain.

Metode Pendidikan Karakter Islami di Madrasah Ibtidaiyah perlu dikembangkan pada pendidikan karakter agar dapat mencapai pertumbuhan integral, dengan mempertimbangkan berbagai macam prinsip penggunaan metode pendidikan yang idealnya memuat nilainilai spiritual. 
Penerapan pendidikan karakter di Madrasah Ibtidaiyah dilakukan pada ranah pembelajaran (kegiatan pembelajaran), pengembangan budaya sekolah dan pusat kegiatan belajar, kegiatan ko-kurikuler dan kegiatan ekstrakurikuler, serta kegiatan keseharian di rumah dan di masyarakat.

\section{Model-Model Penerapan Pendidikan Karakter}

Keberhasilan dalam menyelenggarakan dan menanamkan nilai-nilai kehidupan melalui pendidikan karakter dapat pula dipengaruhi oleh cara ataupun pendekatan yang dipergunakan dalam menyampaikannya. Menurut Suparno (2002) ada empat model pendekatan penyampaian pendidikan karakter, antara lain:

\section{Model sebagai Mata Pelajaran Tersendiri} (Monolitik)

Dalam model pendekatan ini, pendidikan karakter dianggap sebagai mata pelajaran tersendiri. Oleh karena itu, pendidikan karakter mempunyai kedudukan yang sama dan di perlakukan sama seperti pelajaran atau bidang studi lain. Dalam hal ini, guru bidang studi pendidikan karakter harus mempersiapkan dan mengembangkan kurikulum, mengembangkan silabus, membuat rancangan proses pembelajaran (RPP), metodologi pembelajaran, dan evaluasi pembelajaran. Konsekuensinya pendidikan karakter harus dirancangkan dalam jadwal pelajaran yang terstruktur (Suparno, 2002, p. 42).

Kelebihan pendekatan ini antara lain adalah materi yang di sampaikan akan lebih terarah dan terencana matang dan terfokus, materi yang disampaikan lebih terukur. Sedangkan kelemahan pendekatan ini adalah sangat tergantung pada tuntutan kurikulum, kemudian penenaman nilai tersebut seolaholah menjadi tanggung jawab seorang guru semata, demikian pula dampak yang muncul pendidikan karakter hanya menyentuh aspek kognitif, tidak menyentuh internalisasi nilai tersebut (Suparno, 2002, p. 42). Pendekatan model ini adalah pendekatan model lama, dimana nilai-nilai karakter dimuat dalam satu mata pelajaran dan kemudian diajarkan dan di transfer melalui pembelajaran di kelas, banyak para pakar menilai bahwa model ini sudah tidak layak dan tidak mampu untuk menghantarkan siswa-siswi menjadi pribadi yang berkarakter. Karena perkembangan jaman dan juga kondisi yang mengakibatkan perlunya model-model yang lebih membiasakan internalisasi nilai-nilai dalam kehidupan.

\section{Model Terintegrasi dalam Semua Bidang Studi}

Pendekatan yang kedua dalam menerapkan pendididikan karakter adalah disampaikan secara terintegrasi dalam setiap bidang pelajaran, dan oleh karena itu penerapan pendidikan karakter menjadi tanggung jawab semua guru. Dalam konteks ini guru dapat memilih pendidikan karakter yang sesuai dengan tema dan pokok bahasan bidang studi. Melalui model integrasi ini maka setiap guru adalah pengajar pendidikan karakter tanpa terkecuali (Husein, 2010, p. 31).

Keunggulan model terintegrasi pada setiap bidang studi antara lain setiap guru ikut bertanggung jawab akan penanaman nilai-nilai hidup kepada setiap siswa, disamping itu pemahaman nilai-nilai pendidikan karakter cenderung tidak bersifat informative-kognitif, melainkan bersifat aplikatif sesuai dengan konteks pada setiap bidang studi. Dampaknya positifnya terhadap siswa adalah akan lebih terbiasa dengan nilai-nilai yang sudah diterapkan dalam berbagai seting (Husein, 2010, p. 31).

Dan adapun sisi kelemahannya adalah pemahaman dan persepsi tentang nilai yang akan di tanamkan harus jelas dan sama pada semua guru. Namun, mejamin kesamaan pada setiap guru adalah hal yang tidak akan mudah, hal ini mengingat latar belakang dari stiap guru yang berbeda-beda. Di samping itu, jika terjadi perbedaan penafsiran nilai-nilai di antara guru akan mengakibatkan siswa bingung (Husein, 2010, pp. 31-32).

\section{Model di Luar Pengajaran}

Penanaman nilai-nilai karakter dapat juga di tanamkan dan di terapkan di luar kegiatan pembelajaran formal. Pendekatan ini lebih mengutakan pengolahan dan penanaman nilai melalui suatu kegiatan untuk dibahas dan kemudian dibahas nilai-nilai hidupnya. Model kegiatan demikian dapat dilaksanakan oleh guru sekolah yang diberi tugas tersebut atau dipercayakan kepada lembaga lain untuk melaksanakannya. Kelebihan pendekatan ini adalah siswa dapat endapatkan pengalaman secara langsung dan kongkrit. Kelemahannya 
adalah tidak ada dalam struktur tetap dalam kerangka pendidikan dan pengajaran di sekolah, sehingga akan membutuhkan waktu yang lebih lama dan biaya yang lebih banyak (Husein, 2010, p. 32).

\section{Model Gabungan}

Pendekatan model gabungan adalah menggabungkan antara model integrasi dan model luar pengajaran secara bersama. Model ini dapat dilaksanakan dalam kerja sama dengan tim baik oleh guru maupun kerja sama dengan pihak luar sekolah. Kelebihan model ini adalah semua guru terlibat, disamping itu guru dapat belajar dari pihak luar untuk mengembangkan diri dan siswa. Siswa menerima informasi tentang nilai-nilai sekaligus di perkuat dengan pengalaman melalui kegiatankegiatan yang terencana dengan baik. Mengingat pendidikan karakter merupakan salah satu fungsi pendidikan Nasional, maka sepatutnya pendidikan karakter ada pada setiap materi pelajaran (Husein, 2010, p. 32).

Dari beberapa model di atas adalah model implementasi pendidikan karakter yang mempunyai kelebihan dan kekurangannya masing-masing, namun beberapa model diatas juga sudah mulai dikembangkan oleh para pakar dan ahli karena di anggap sudah tidak mampu menghantarkan peserta didik menjadi pribadi-pribadi yang bermartabat dan berkarakter baik. Namun bukan berarti model lama dilupakan begitu saja, akan tetapi tetap digunakan namun dikembangkan sehingga akan mempermudah untuk tercapainya tujuan pendidikan yakni menjadikan peserta didik menjadi insan-insan yang beriman dan bertaqwa kepada tuhan yang maha esa, berakhlak mulia, sehat, berilmu, cakap, kreatif, mandiri, bertanggung jawab dan menjadi warga Negara yang demokratis.

\section{Pengembangan Silabus dan RPP untuk Pendidikan karakter}

Peraturan Menteri Pendidikan Nasional Republik Indonesia nomor 22 Tahun 2006 (Menteri Pendidikan Nasional, 2006) tentang Standar Isi untuk Satuan Pendidikan Dasar dan Menengah, pedoman penyusunan silabus dan RPP, kemudian teori-teori pendidikan karakter. guru harus memahami KI-KD secara cermat dan dengan menggunakan perspektif pendidikan karakter.
Guru memiliki otoritas penuh dalam mengambangkan silabus dan RPPnya sendiri. Hal pokok yang harus ditaati setiap guru adalah bahwa dalam silabus dan RPP tersebut telah memuat ketentuan minimal silabus dan RPP seperti yang telah ditetapkan oleh Badan Standar Nasional Pendidikan (BSNP).

Samani \& Hariyanto (2011, p. 176) menjelaskan bahwa rencana nasional dalam implemantasi pendidikan karakter telah ditetapkan pada mata pelajaran yang berdampak pembelajaran (Instructional effect) sekaligus dampak pengiring (nurturant effect), juga ada mata pelajaran yang hanya memiliki dampak pengiring. Mata pelajaran yang disepakati memiliki dampak keduanya ialah Pendidikan Agama dan Pendidikan Kewarganegaraan (PKn). Mata pelajaran yang lain hanya memiliki dampak pengiring. Dengan demikian dalam mata pelajaran Pendidikan Agama dan Pendidikan Kewarganegaraan nilai-nilai karakter tertentu yanag relevan wajib diukur dan dinilai baik dalam penilaian formatif maupun dalam penilaian sumatif, sementara itu dalam mata pelajaran yang lain, nilai-nilai karakter tertentu yang relevan diintegrasikan dalam kegiatan pembelajaran dan diobservasi melalui lembar pengamatan afektif.

Guru diberi keleluasaan untuk mengembangkan dan memasukkan nilai-nilai karakter tersebut dalam silabus dan RPP. Ciri bahan ajar akan mengilhami guru tentang nilai karakter yang akan dikembangkan, lebih konkretnya terlihat dalam tujuan pembelajaran. Setelah indikator pembelajaran dalam silabus, di sebelah indikator dapat disediakan kolom bagi nilai karakter yang dapat dikembangkan. Sementara itu dalam RPP, jenis metode pembelajaran yang dipilih juga menentukan nilai karakter yang akan dikembangkan.

\section{SIMPULAN}

Dari pembahasan di atas dapat disimpulkan bahwa: (1) konsep pendidikan karakter di Madrasah Ibtidaiyah dimaknai sebagai bentuk kurikulum yang memuat materi-materi pendidikan karakter yang diperuntukkan bagi pembelajaran anak sejak dini. Di mana tujuannya ialah untuk mengenalkan dan menanamkan karakter kejujuran, loyalitas dan dapat diandalkan, hormat, cinta, ketidak egoisan dan sensitifitas, baik hati dan pertemanan, keberanian, kedamaian, mandiri dan potensial, disiplin diri, kesetiaan dan kemurnian, keadilan dan 
kasih sayang. (2) model pengembangan pendidikan karakter di Madrasah Ibtidaiyah dilakukan dengan memperhatikan tujuan, karakteristik anak, prinsip dan nilai karakter. Adapun model pendekatan yang dapat digunakan dan di implementasikan dalam pendidikan karakter di Madrasah Ibtidaiyah yaitu model terintegrasi pada semua bidang studi dan model gabungan.

Dari kesimpulan di atas, saran yang dapat menjadi pertimbangan adalah dalam pengembangan pendidikan karakter sebaiknya menyesuaikan dengan tema dan sumber belajar yang terdekat dengan sekolah, sehingga tidak membebani sekolah, orang tua, maupun anak yang bersangkutan. Selain itu, dibutuhkan kreativitas dan kesungguhan dari guru dalam pengembangan pendidikan karakter di Madrasah Ibtidaiyah.

\section{DAFTAR PUSTAKA}

Asmani, J. M. (2012). Buku panduan internalisasi pendidikan karakter di sekolah. Yogyakarta: Diva Press.

Battel, J. A., \& Shannon, R. L. (1978). Gagasan baru dalam pendidikan. (S. S. Hutabarat, Trans.). Jakarta: Mutiara.

Fadiman, C. (1984). Children's literature. In Encyclopedia Britannica (15th ed., p. 216).

Goleman, D. (2001). Kecerdasan emosional. (T. Hermaya, Trans.). Jakarta: Gramedia Pustaka Utama.

Husein, A. (2010). Model pendidikan karakter bangsa. Jakarta: UNJ.

Izzaty, R. E., Suardiman, S. P., Ayriza, Y., Hiryanto, \& Kusmaryani, R. E. (2008). Perkembangan peserta didik. Yogyakarta: UNY Press.

Kesuma, D., Triatna, C., \& Permana, J. (2011). Pendidikan karakter kajian teori dan praktik di sekolah. Bandung: Rosda Karya.

Kirschenbaum, H. (2000). From values clarification to character education: A personal journey. The Journal of Humanistic Counseling, Education and Development, 39(1), 4-20.

Koesoema, D. (2010). Pendidikan karakter; strategi mendidik anak di zaman global.
Jakarta: Grasindo.

Lickona, T. (2008). Pendidikan karakter panduan lengkap mendidik siswa menjadi pintar dan baik. New York: Bantam Book.

Listyarti, R. (2012). Pendidikan karakter dalam metode aktif, inovatif dan kreatif. Jakarta: Erlangga.

Menteri Pendidikan Nasional. Peraturan menteri pendidikan nasional nomor 22 tahun 2006 standar isi (2006).

Muslich, M. (2011). Pendidikan karakter: menjawab tantangankrisis multidimensional. Jakarta: Bumi Aksara.

Nashir, H. (2013). Pendidikan karakter berbasis agama \& budaya. Yogyakarta: Multi Presindo.

Samani, M., \& Hariyanto. (2011). Konsep dan model pendidikan karakter. Bandung: Rosdakarya.

Sugihartono, Fathiyah, K. N., Harahap, F., Setiawati, Fa. A., \& Nurhayati, S. R. (2007). Psikologi pendidikan. Yogyakarta: UNY Press.

Sugiyono. (2011). Metode penelitian kuantitatif, kualitatif dan $R \& D$. Bandung: Alfabeta.

Suparno, P. (2002). Pendidikan budi pekerti di sekolah. Yogyakarta: Kanisius.

Suryadi, A. (2011). Pendidikan karakter bangsa: Pendekatan jitu menuju sukses pembangunan pendidikan nasional, dalam pendidikan karakter: Nilai inti bagi upaya pembinaan kepribadian bangsa. Bandung: Widya Aksara Press.

Syarbni, A. (2012). Buku pintar pendidikan karakter. Panduan lengkap mendidik karakter anak di sekolah, madrasah dan rumah.Jakarta: as@-Prima.

Wibowo, T. (2010). Pentingnya pendidikan karakter dalam dunia pendidikan. Retrieved July 18, 2018, from http://www.pendidikankarakter.com/pent ingnyapendidikan-karakter-dalam-duniapendidikan/

Zubaedi. (2011). Desain pendidikan karakter konsepsi dan aplikasinya dalam lembaga pendidikan. Jakarta: Kencana Prenada Media Grup. 